\title{
Avulsion Dynamics in a River with Alternating Bedrock and Alluvial Reaches, Huron River, Northern Ohio (USA)
}

\author{
Mark J. Potucek ${ }^{1,2}$, James E. Evans ${ }^{1}$ (1) \\ ${ }^{1}$ Department of Geology, Bowling Green State University, Bowling Green, OH, USA \\ ${ }^{2}$ Arizona Department of Water Resources, Phoenix, AZ, USA \\ Email: evansje@bgsu.edu
}

How to cite this paper: Potucek, M.J. and Evans, J.E. (2019) Avulsion Dynamics in a River with Alternating Bedrock and Alluvial Reaches, Huron River, Northern Ohio (USA). Open Journal of Modern Hydrolo$g y, 9,20-39$.

https://doi.org/10.4236/ojmh.2019.91002

Received: December 19, 2018

Accepted: January 20, 2019

Published: January 23, 2019

Copyright $\odot 2019$ by author(s) and Scientific Research Publishing Inc. This work is licensed under the Creative Commons Attribution International License (CC BY 4.0).

http://creativecommons.org/licenses/by/4.0/

\begin{abstract}
The Huron River consists of alternating bedrock reaches and alluvial reaches. Analysis of historical aerial photography from 1950-2015 reveals six major channel avulsion events in the 8-km study area. These avulsions occurred in the alluvial reaches but were strongly influenced by the properties of the upstream bedrock reach ("inherited characteristics"). The bedrock reaches aligned with the azimuth of joint sets in the underlying bedrock. One inherited characteristic in the alluvial reach downstream is that the avulsion channels diverged only slightly from the orientation of the upstream bedrock channel (range $2^{\circ}-38^{\circ}$, mean and standard deviation $12.1^{\circ} \pm 13.7^{\circ}$ ). A second inherited characteristic is that avulsion channels were initiated from short distances downstream after exiting the upstream bedrock channel reach (range $62-266 \mathrm{~m}$, mean and standard deviation $143.7 \pm 71.0 \mathrm{~m}$ ), which is a fraction of the meander wavelength $(1.2 \mathrm{~km})$. Field evidence shows that some avulsion channel sites were re-occupied episodically. In addition, two properties were necessary for channel avulsions: 1) avulsion events were triggered by channel-forming hydrologic events (5-year recurrence interval flows), but not every channel-forming hydrologic event resulted in an avulsion, and 2) channel sinuosity $(\mathrm{P})$ increased to $1.72-1.77$ prior to an avulsion then decreased to $1.65-1.70$ following an avulsion, suggesting that $\mathrm{P} \geq 1.72$ is the "critical sinuosity" or triggering value for avulsions on the Huron River. In summary, for this river consisting of alternating bedrock and alluvial reaches, the bedrock reaches impose certain parameters on downstream alluvial reaches (including sediment supply, channel direction and avulsion channel position downstream after exiting a bedrock reach) while adjustments in sinuosity and sediment storage occur in the alluvial reaches.
\end{abstract}




\section{Keywords}

Avulsion, Bedrock Channels, Alluvial Channels, Cut-Offs, Historical

Changes, Fluvial Sediment Budgets

\section{Introduction}

\subsection{Purpose}

This study evaluates a river that consists of alternating alluvial and bedrock reaches. An alluvial channel is understood to have bed and bank materials that consist of loose sediment, possibly including gravel. A bedrock channel has been variously defined as having bed or bank materials that are $>50 \%$ lithified rocks or cemented alluvium [1] or, alternatively, channel beds that lack even a thin continuous alluvial cover [2] [3]. There can be practical field problems with defining a bedrock channel because continuously exposed bedrock surfaces in channels are relatively rare, while patchy alluvial cover on top of bedrock is more typical (sometimes called "mixed bedrock-alluvial channels"). However, there is a clear contrast between these and the temporally and spatial continuous sediment cover present in alluvial channels [2]. A river consisting of alternating alluvial and bedrock reaches, like the Huron River (northern Ohio, USA) is generally understood to be the result of transitions between bedrock reaches where transport capacity exceeds sediment supply and alluvial reaches where sediment supply exceeds transport capacity [3].

It has long been recognized that fluvial geomorphology concepts developed from the study of alluvial channels, while bedrock channels exhibit significant differences in hydrologic processes and evolution of geomorphic features [1]. For example, high-magnitude floods in bedrock channels can produce distinctive hydraulic phenomena such as macroturbulent eddies (kolks), boulder transport, and hydraulic jumps; and also produce unique sedimentary features such as giant ripple marks, pendant bars, eddy bars, expansion bars, and elevated slackwater deposits [4] [5]. In bedrock channels, channel bed or bank erosion proceeds by hydraulic quarrying of bedrock blocks along bedding or joint surfaces, cavitation, and weathering/dissolution [6] [7]. Erosional scours (potholes) form at the intersection of bedrock fractures and are often infilled by distinctive pool-fill deposits [8]. Bedrock surfaces commonly exhibit smoothed rock surfaces [1], grooves, lineations, spindle-shaped and parabolic troughs, and faceted rock faces [9]. Channel bedforms are typically gravel-rich and form in the lee of obstacles or at places of flow divergence [4]. Erosional and depositional processes in bedrock channels depend on many factors, including lithology, orientation and spacing of discontinuities (joints, fractures, bedding), and weathering processes [7], availability of detached bedrock clasts to act as "tools" to abrade the channel bed [10], and also the magnitude and frequency of large flood events [9] [11]. 
Bedrock channels adjust to hydrologic change in a variety of ways. Incision can result downstream from landslide dams [12] or large wood debris (LWD) accumulations [13] in bedrock channels. Incision may produce strath terraces composed of bedrock treads mantled by alluvium, and these features can facilitate enhanced bedrock weathering, strath terrace abandonment, and further incision during high magnitude flow events [14]. Lateral shifts in position of bedrock channels is generally limited and strongly controlled by the lithology and underlying structure such as joint patterns, but channel shifting can occur if flood flows exceed the transport capacity of bedrock canyons [4]. In contrast, alluvial rivers develop characteristic channel patterns determined by imposed hydrologic regime, sediment load, and channel bank stability [15]. Alluvial channels adjust to hydrologic change by aggrading or degrading, by changes in hydraulic geometry, by changes in channel pattern, and by lateral shifts in the position of the channel, including point bar migration, neck cut-offs, chute cut-offs, and channel avulsions (channel shifting events).

Channel avulsions play a major role in the geomorphic development of alluvial channels and floodplains, redistributing water and sediment across a broad spectrum of environments [16]. Multiple causes for channel avulsions have been proposed, but the main mechanisms are considered to be either increased aggradation rates or decreases in water or sediment transport capacity due to sinuosity increases or local channel constrictions [16] [17] [18] [19] [20].

The Huron River (northern Ohio, USA.) consists of alternating alluvial and bedrock reaches, and has a documented recent history of avulsions occurring in the alluvial reaches, based upon historical aerial photographs between 1950-2015. The purpose of this paper is to determine the properties of the avulsion events in the alluvial reaches, as influenced by the upstream bedrock reaches. Our hypothesis is that some of the properties of the upstream bedrock reaches are "inherited" by the downstream alluvial reaches and result in consistent development of avulsion channels, including episodic re-occupation of certain avulsion sites.

\subsection{Background}

The Huron River is approximately $96-\mathrm{km}$ in length, flowing north across northern Ohio into Lake Erie, one of the Laurentian Great Lakes (Figure 1). The river has a drainage basin of $1044 \mathrm{~km}^{2}$ [21]. The river is divided into two major branches, the East Branch and West Branch. The West Branch is $80-\mathrm{km}$ in length, and this study examines the $8-\mathrm{km}$ reach just upstream of the junction of the East and West branches (between river kilometers (RK) 28 - 36). The West Branch sources at an elevation of 332-m above mean sea level (msl), and joins the East Branch at an elevation of $180-\mathrm{m} \mathrm{msl}$, with a mean slope of $2 \times 10^{-3}$. The West Branch is found in a hilly region called the Allegheny Escarpment, which consists of bedrock hills having topographic relief up to $175-\mathrm{m}$ above the bed of the adjacent stream.

There is a US Geological Survey (USGS) gaging station located about $3 \mathrm{~km}$ downstream of the junction of the West and East branches (at RK 20.6). This 


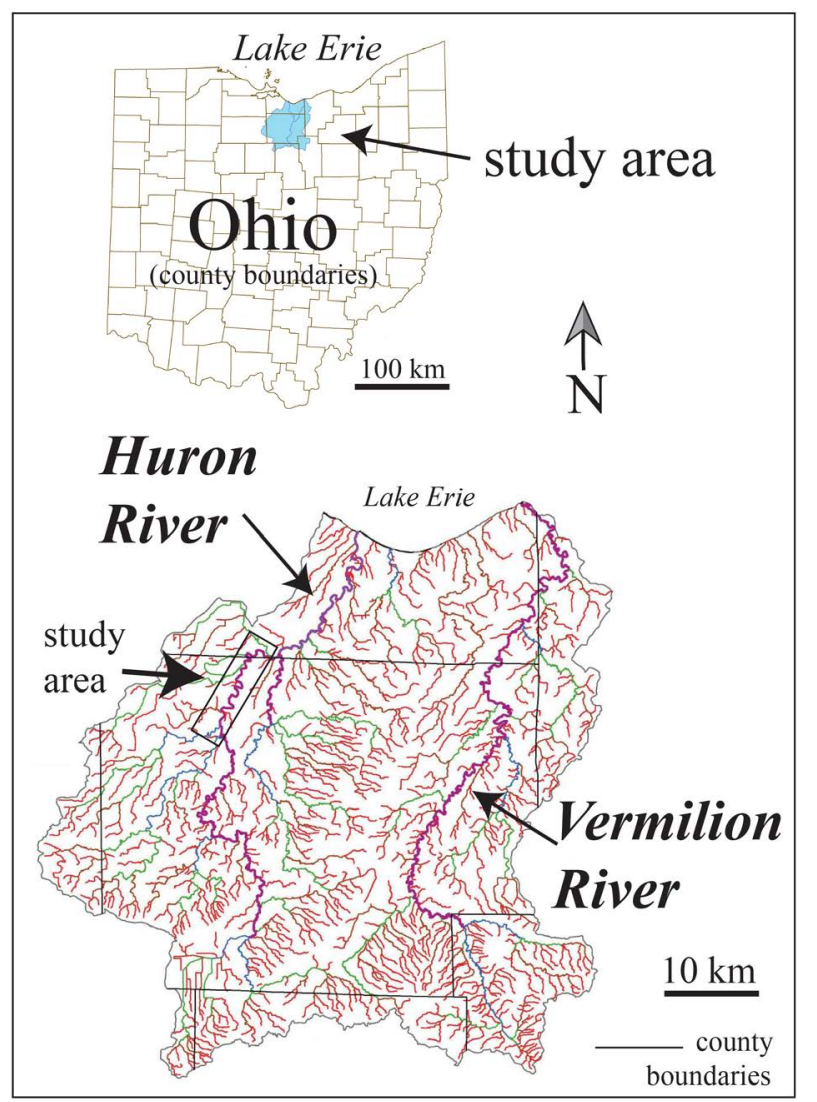

Figure 1. Location map showing the Huron River and Vermilion River watersheds in north-central Ohio, draining north into Lake Erie. The study area is an $8-\mathrm{km}$ reach located on the Western Branch of the Huron River.

station (USGS 04199000) has continuous gage records from 1950-2018 except for a 7 -year data gap between September 1980-October 1987. The gage is located in the town of Milan, Ohio, on a bridge pier of US Highway 250, at an elevation of 174-m.msl [22]. Just downstream of the USGS gage station the Huron River enters the Lake Erie coastal plain, which has an average stream gradient of $3.3 \times$ $10^{-5}$. During the study interval from 1950-2018, the Huron River had average discharge of $8.7 \mathrm{~m}^{3} \cdot \mathrm{s}^{-1}$, with peak discharge of $1389 \mathrm{~m}^{3} \cdot \mathrm{s}^{-1}$ on 5 July 1969. At the gage station, stage height varied from minimum of $3.8-\mathrm{m}$ to maximum of $9.5-\mathrm{m}$. Major hydrologic events can be characterized as having $\mathrm{Q}>300 \mathrm{~m}^{3} \cdot \mathrm{s}^{-1}$ and/or stage height $>6.0 \mathrm{~m}$ at the gage station [23].

The study area consists of alternating reaches of bedrock channels and alluvial channels (Figure 2). The bedrock channel reaches exhibit outcrops of the Huron Shale Member of the Ohio Shale, a fissile, silica-cemented, carbonaceous black shale unit up to 122-m thick in northern Ohio [24]. This unit, or its stratigraphic equivalents, is found throughout the Appalachian Basin as part of a regional marine anoxia event during the Late Devonian [25]. Clasts from this unit enter the Huron River either by rockfall from bedrock cliffs or by hydraulic quarrying of the stream bed. Blocks of shale often shatter into oblate (discoid) shaped clasts 


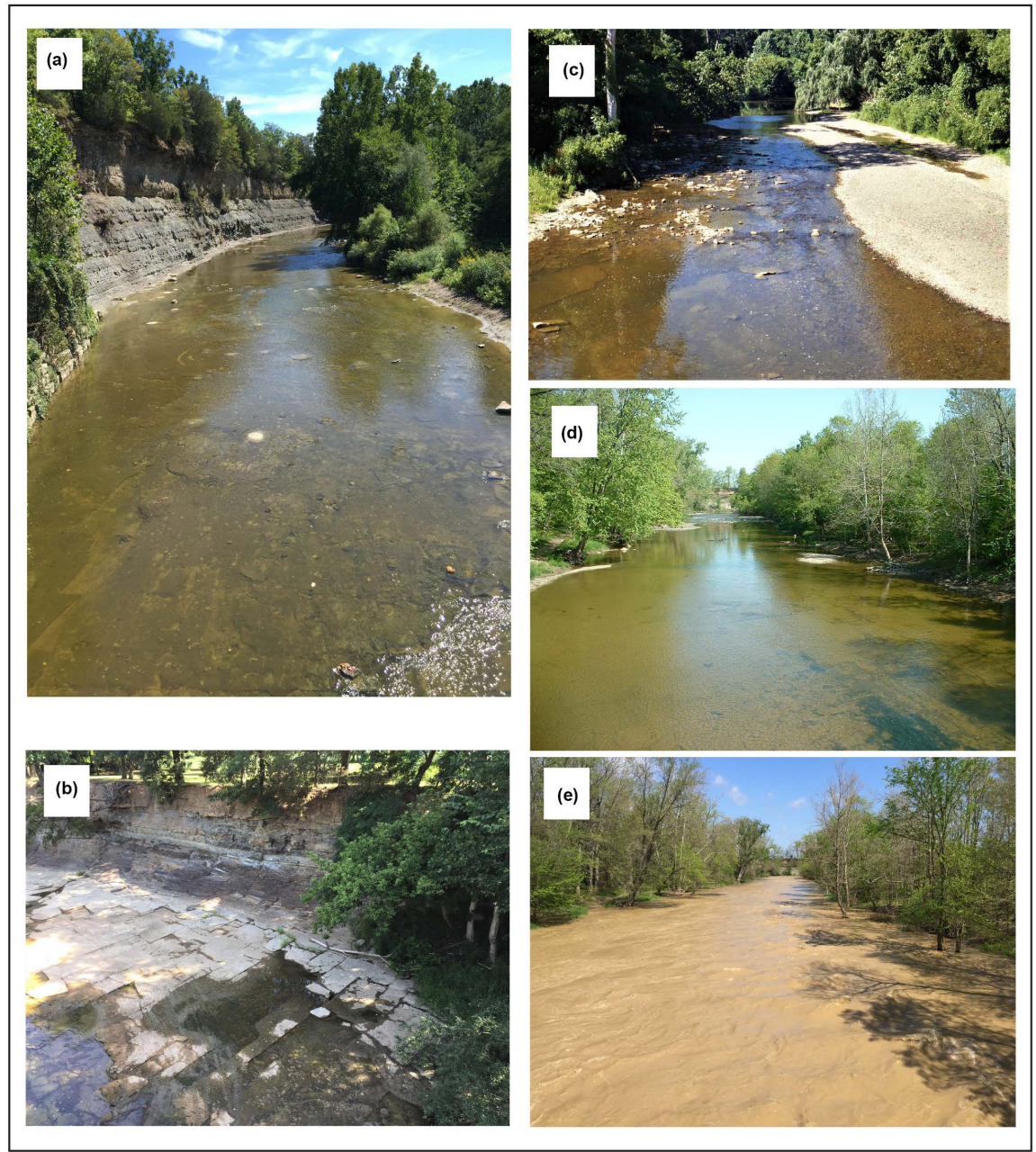

Figure 2. Field photographs showing (a) bedrock channel reach with shale cliffs and channel bed, (b) bedrock channel reach at low-stage, showing orthogonal joint sets, (c) lateral bar and riffle in alluvial channel reach, (d) alternate bar-pool topography and low alluvial banks, and (e) high flow stage in the same reach as (d).

that are transported downstream to form gravel bars with imbricated fabric. The stream bed often exhibits prominent jointing (Figure 2(b)) with approximately orthogonal sets of fractures. In the bedrock channel reaches, alluvium covering the bedrock channel bottom is patchy or discontinuous. Occasional boulder-sized clasts consist of carbonate nodules that eroded from the shale cliffs. Bedrock channels are typically shallow flows over exposed bedrock surfaces, quarried "pools" up to 2-m deep, and occasional riffles consisting of gravel clasts wedged into bedrock fractures.

The alluvial reaches consist of alternating bar-and-pool topography with gravel medial, lateral, point, and confluent bars, with continuous alluvial cover on the stream bed (Figure 2(c)). Individual bars range from 33 to 204-m in length and 34 to $109-\mathrm{m}$ in width [26]. In these sedimentation zones, the bars migrate downstream or across-stream at rates up to $9 \mathrm{myr}^{-1}$ [26]. Alluvial banks are low vegetation-covered sands and muds (Figure $2(\mathrm{~d})$ ) that are readily overtopped 
during flood stage (Figure 2(e)). The alluvial channels are sinuous, single or multiple channels that fit the definitions of a "wandering gravel channel" [27] [28].

\section{Methods}

\subsection{Historical Aerial Photographs}

Nine historical aerial photograph sets were obtained of the study area between 1950-2015. The sources for the aerial photographs include the United States Department of Agriculture, Natural Resources Conservation Service (USDA-NRCS), United States Geological Survey, Earth Resources Observation and Science Center (USGS-EROS), the Erie County Auditor's Office (a local government agency), and the State of Ohio, Geographically Referenced Information Program (OGRIP). Characteristics of the images are summarized in Table 1. The 2015 image, provided by OGRIP, is a Digital Ortho Quarter Quadrangle (DOQQ) image which has been georectified to an existing State of Ohio 0.76-m (2.5-ft) digital elevation map (DEM). This image was used as the base image for comparisons among the other aerial photographs. The other images included paper copies of images that were scanned and imported into a geographical information system (GIS).

This study used ESRI ArcMAP version $10.3 .1^{\circ}$ as a GIS platform to overlay the georeferenced historical aerial photograph images on the 2015 DOQQ. Each image was georeferenced using a constellation of ground control points (GCPs) located at consistent features in all of the images, such as the geographical position of bridge abutments. Individual images were stretched or shrunk using a polynomial best-fit triangulation method to closely match the position of the GCPs on the 2015 DOQQ. The root mean square (RMS) error for these best-fits is given in Table 1 , and is typically $<1.5-\mathrm{m}$ (mean RMS error $\pm 1.1-\mathrm{m}$ ), which is significantly smaller than the scale of the geomorphic changes discussed in this paper. Further details are given in elsewhere [23] [26].

The properties of each channel avulsion "inherited" from the upstream bedrock channel reach include exit angles and exit distances. Exit angles were calculated by comparing the average azimuth of the upstream bedrock channel reach to the azimuth of the upstream part of the avulsion channel (i.e., where the avulsion channel leaves the main channel). The exit distance is the direct path distance between the downstream end of the bedrock channel reach and the upstream end of the avulsion channel.

\subsection{Field and Laboratory Work}

Field work included ground-truthing GCPs, excavating trenches along stream banks, collecting vibracores, textural analysis of gravels in the field, and measuring joint sets. Laboratory work included sediment core analysis and sand sieve analysis for grain size. Both trenches and cores were used for stratigraphy and facies analysis. 
Table 1. Aerial photograph data base.

\begin{tabular}{ccccc}
\hline Date Acquired & Source & Image Format & Scale & RMS Error (m) \\
\hline 21-Oct-1950 & USDA-NRCS & Black-and-White & $1: 1320$ & 0.57 \\
16-May-1960 & USGS-EROS & Black-and-White & $1: 60,000$ & 0.81 \\
22-Mar-1969 & USGS-EROS & Black-and-White & $1: 24,000$ & 1.62 \\
29-Apr-1977 & USGS-EROS & Black-and-White & $1: 80,000$ & 1.06 \\
20-Sep-1979 & USDA-NRCS & Black-and-White & $1: 1320$ & 1.22 \\
9-Apr-1988 & USGS-EROS & Infrared & $1: 40,000$ & 1.50 \\
15-Mar-1995 & USGS-EROS & Black-and-White & $1: 12,000$ & 1.35 \\
1-Apr-2001 & Erie County Auditor Office & Black-and-White & $1: 12,000$ & 0.45 \\
3-Jan-2015 & OGRIP & DOQQ & & Base Image \\
\hline
\end{tabular}

Explanation: USDA-NRCS is US Department of Agriculture, Natural Resources Conservation Service. USGS-EROS is US Geological Survey, Earth Resources Observation and Science Center. Erie County Auditor Office is a local government entity for tax assessment purposes. OGRIP is the Ohio Geographically Referenced Information Program (State of Ohio). DOQQ is a Digital Ortho Quarter Quadrangle image georectified to an existing statewide 2.5 foot DEM. The DOQQ served as the base image and previous images projected on to it (RMS error shown).

This study excavated 11 trenches at six locations representing the entrance and exit positions of avulsion channels that formed between 1950-2015. These were typically cutbank sites where the exposure was cleared and deepened to remove slopewash. The stratigraphy of each site was logged using Sedlog ${ }^{\circledR}$. Gravel grain size analyses were conducted in the field by measuring dimensions of the short-, intermediate-, and long-axis of each clast using a caliper. Approximately 20 clasts were measured per gravel bed. The average grainsize was calculated as the average of the intermediate diameter of the 10 largest clasts. Sand samples were sieved in the laboratory.

Eight $7.6 \mathrm{~cm}$-diameter vibracores were recovered in the vicinity of several avulsion channels, ranging from $75-\mathrm{cm}$ to $147-\mathrm{cm}$ in length. The aluminum core barrels of each core were split lengthwise, one half archived, and the other half cleaned, logged using Sedlog ${ }^{\oplus}$, and sampled for sand grain size analysis. Sieve analysis followed ASTM protocol [29]. Grain size data was evaluated statistically using standard methods [30].

The trenches and vibracores were used for facies analysis. Twelve lithofacies were defined, using combinations of lithology, texture, and sedimentary structures (Table 2). The lithofacies were grouped into characteristic lithofacies assemblages. The lithofacies assemblages and sequences were used to interpret the depositional environments and evolution of individual avulsion channels [31].

Bedrock fractures in the bed of the Huron River occur in joint sets. The azimuths of individual fractures were measured at low-flow stage by wedging a thin board into the open fracture and then using a Brunton compass to measure the azimuth. The location of these measurements was determined using GPS. The joint data was imported into GIS and projected on the 2015 DOQQ at those locations. Finally, the composite data was plotted on a non-linear rose diagram 
Table 2. Lithofacies descriptions.

\begin{tabular}{ccccc}
\hline Code & Lithology & Textures & Sedimentary Structures & Interpretation \\
\hline $\mathrm{Gm}$ & gravel & pebble-cobble & massive & gravel bar platform \\
$\mathrm{Gmi}$ & gravel & pebble-cobble & massive, imbricated & gravel bar-head \\
$\mathrm{Smc}$ & sand & coarse-grained & massive & suprabar platform \\
$\mathrm{Smf}$ & sand & fine-grained & massive & proximal overbank \\
$\mathrm{St}$ & sand & medium-grained & trough cross-bedded & dunes \\
$\mathrm{Sr}$ & sand & fine-grained & ripple laminated & ripples \\
$\mathrm{Sl}$ & sand & fine-grained & planar lamination & proximal overbank \\
$\mathrm{SSl}$ & silt & coarse-grained & planar laminated & proximal overbank \\
$\mathrm{SSm}$ & silt & coarse-grained & massive & proximal overbank \\
$\mathrm{Fl}$ & mud & silt and clay & planar laminated & distal overbank \\
Fm & mud & silt and clay & massive & distal overbank \\
$\mathrm{P}$ & mixed & mixed & roots & modern/recent soil \\
\hline
\end{tabular}

[32] calculating vector mean, circular standard deviation [33], and Rayleigh test of significance [34].

\section{Results}

\subsection{Location and History of Avulsion Channels}

When the georeferenced aerial photographs from 1950, 1960, 1969, 1977, 1979, 1988, 1995, and 2001 are projected onto the 2015 georectified DOQQ, there are six channel avulsions that can be observed representing changes greater than the mean RMS error (ranging from $0.45-1.62 \mathrm{~m}$ ). These avulsions occurred in the alluvial reaches between bedrock reaches (Figure 3 ).

Three channel avulsions occurred between the 1950 and 1960 historical aerial photographs. The position of these avulsion channels is shown in Figure 4(a). The reach labelled C1 is where a split channel in 1950 led to the western channel being abandoned and partially infilled by 1960 . The reach labelled C2 is where a chute channel cut-off occurred between 1950-1960, resulting in abandonment and partial infilling of the former single channel. The reach labelled C3 is where multiple channels on either side of a mid-channel bar in 1950 resulted in abandonment and partial infilling of the southern channel by 1960 . There were no avulsions between the 1960 and 1969 historical aerial photographs. By 1969, the changes noted above continued to progress, with enlarging of the new main channels and infilling of the older, abandoned channels.

One channel avulsion occurred between the 1969 and 1977 historical aerial photographs. The reach labelled C4 (Figure $4(\mathrm{~b})$ ) is where a chute channel cut-off occurred, resulting in abandonment and partial infilling of the former (eastern) main channel by 1977. There were no avulsions between the 1977 and 1979 historical aerial photographs. However, flow was re-established in the main 


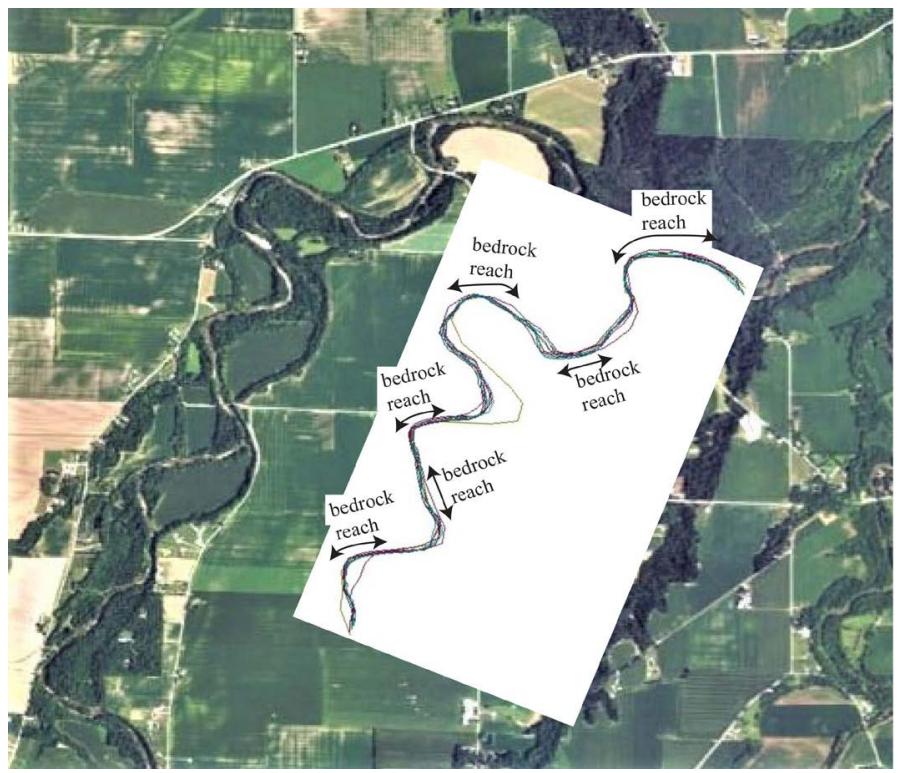

Figure 3. Base image (2015 DOQQ) with insert showing locations of bedrock reaches and locations of channel avulsions between 1950-2015.
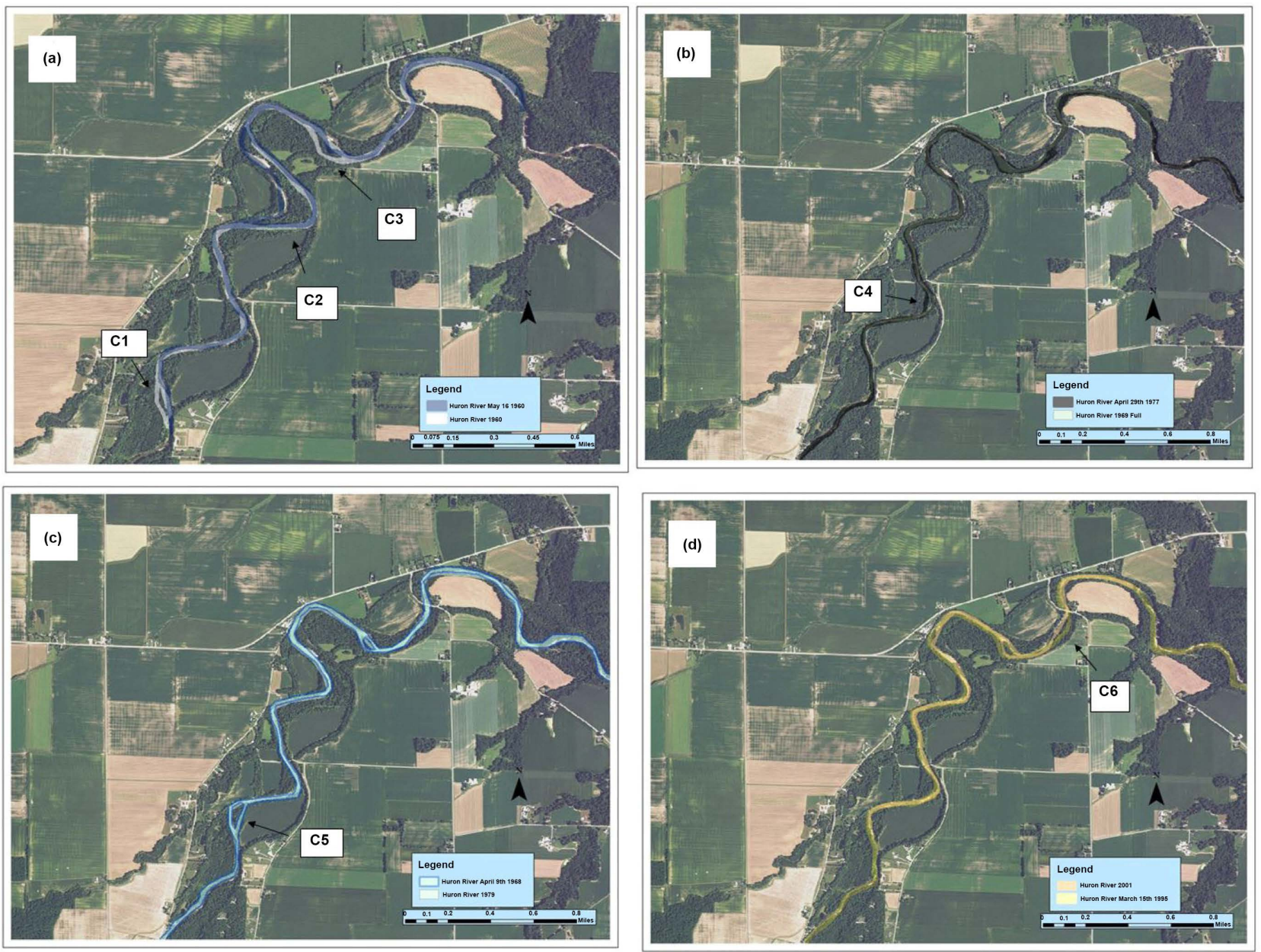

Figure 4. Base 2015 DOQQ modified to show locations of avulsion channels (a) between 1950-1960, (b) between 1969-1977, (c) between 1979-1988, and (d) between 1995-2001. 
channel at C4 by 1979, and the former (western) avulsion channel was abandoned.

One channel avulsion occurred between the 1979 and 1988 historical aerial photographs. The reach labelled C5 (Figure $4(\mathrm{c})$ ) is where a chute channel cut-off formed between 1979-1988, resulting in abandonment and partial infilling of the former main channel. There were no avulsions between the 1988 and 1995 historical aerial photographs.

One channel avulsion occurred between the 1995 and 2001 historical aerial photographs. The reach labelled C6 (Figure 4(d)) is where a chute channel developed around a mid-channel bar by 2001. There were no avulsions between the 2001 and 2015 imagery. However, flow was re-established in the main channel at C6 by 2015, and the former chute channel was abandoned.

\subsection{Hydrologic Controls over Avulsions}

Hydrograph data from USGS gage station 04199000, located $3 \mathrm{~km}$ downstream of the study area, was used to match historical avulsions to known hydrologic events. The hydrograph (Figure 5) identifies 19 peak events summarized in Table 3. The mean annual discharge for the Huron River between 1950-2015 is 300 $\mathrm{m}^{3} \cdot \mathrm{s}^{-1}$. Using the rating curve [23], this corresponds to a stage height of about $6.0 \mathrm{~m}$. We identify specific flow conditions where $\mathrm{Q}>300 \mathrm{~m}^{3} \cdot \mathrm{s}^{-1}$ and/or stage height $>6.0 \mathrm{~m}$ as "channel-forming hydrologic events". These values correspond to the 5 -year recurrence interval $(\mathrm{p}=0.20)$ for the Huron River.

Table 3 shows that there were three instances of channel-forming hydrologic events between 1950-1960, corresponding to when three channel avulsions ( $\mathrm{C} 1$, C2, and C3) occurred. One of those hydrologic events, on 22 January 1959, was the second largest flow event of record $\left(\mathrm{Q}=722 \mathrm{~m}^{3} \cdot \mathrm{s}^{-1}\right.$ and stage height $\left.=7.3 \mathrm{~m}\right)$. It is possible that all three avulsions occurred during this event. There were two channel-forming hydrologic events between 1969-1977, corresponding to when one avulsion (C4) occurred. One of those hydrologic events, on 5 July 1969, was the largest flow event of record $\left(\mathrm{Q}=1389 \mathrm{~m}^{3} \cdot \mathrm{s}^{-1}\right.$ and stage height $\left.=9.5 \mathrm{~m}\right)$. There was one event falling slightly below the channel-forming criteria between 1979-1988. In this case the flow event on 14 April $1979 \mathrm{had} \mathrm{Q}=269 \mathrm{~m}^{3} \cdot \mathrm{s}^{-1}$ and stage height $=5.9 \mathrm{~m}$. There was one avulsion (C5) during this interval. Finally, there were two channel-forming hydrologic events between 1995-2001, during which time interval avulsion C6 occurred.

On the other hand, there were numerous channel-forming hydrologic events during intervals of no new avulsions (1960-1969, 1977-1979, 1988-1995, and 2001-2015). In two cases, adjustments included abandonment of avulsion channels and re-establishment of previous main channels (1977-1979 and 2001-2015). The number of channel-forming events per year varies randomly from 0.11 to 0.50 . There are no trends to the data set. It is evident that significant hydrologic events (measured by discharge and/or stage height) are necessary but not sufficient conditions for avulsion events on the Huron River. 


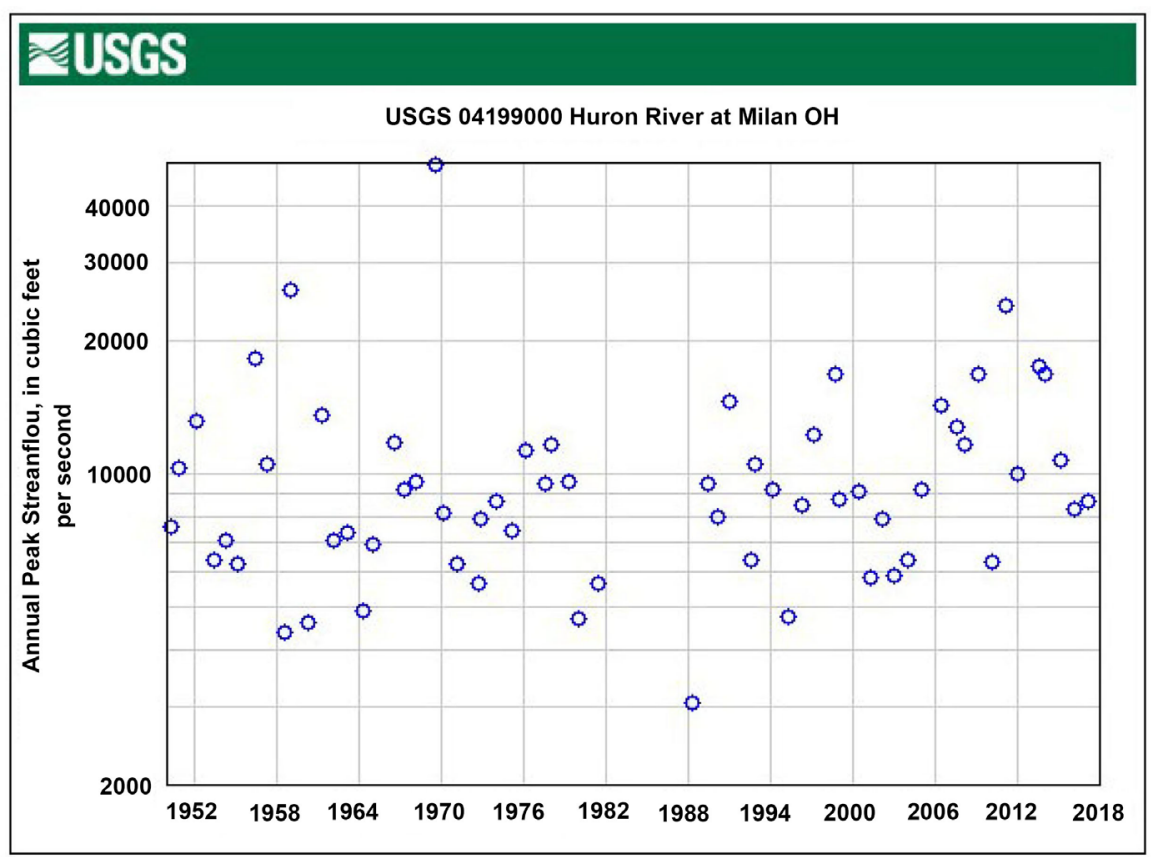

Figure 5. Hydrograph data for the Huron River between 1950-2017. Source: USGS-NWIS, gage station 04199000, Huron River at Milan, Ohio.

Table 3. Channel-forming hydrologic events.

\begin{tabular}{|c|c|c|c|c|}
\hline $\begin{array}{l}\text { Number of } \\
\text { Avulsions }\end{array}$ & $\begin{array}{l}\text { Interval between } \\
\text { Aerial Photographs }\end{array}$ & $\begin{array}{c}\text { Date of Channel-Forming } \\
\text { Hydrologic Event }\end{array}$ & $\begin{array}{l}\text { Peak Streamflow } \\
\qquad\left(\mathrm{m}^{3} \cdot \mathrm{s}^{-1}\right)\end{array}$ & $\begin{array}{l}\text { Stage Height } \\
\text { (m) }\end{array}$ \\
\hline \multirow[t]{3}{*}{3} & $1950-1960$ & 11-Mar-1952 & 370 & 6.0 \\
\hline & & 12-May-1956 & 510 & 6.4 \\
\hline & & 22-Jan-1959 & 722 & 7.3 \\
\hline \multirow[t]{2}{*}{0} & 1960-1969 & 26-Apr-1961 & 381 & 6.0 \\
\hline & & 12-Jul-1966 & 330 & 6.1 \\
\hline \multirow[t]{2}{*}{1} & 1969-1977 & 5-Jul-1969 & 1389 & 9.5 \\
\hline & & 17-Feb-1976 & 316 & 6.2 \\
\hline 0 & 1977-1979 & 15-Dec-1977 & 325 & 6.3 \\
\hline 1 & 1979-1988 & 14-Apr-1979 & 269 & 5.9 \\
\hline 0 & 1988-1995 & 13-Nov-1992 & 294 & 6.1 \\
\hline \multirow[t]{2}{*}{1} & $1995-2001$ & 27-Feb-1997 & 345 & 6.3 \\
\hline & & 26-Aug-1998 & 470 & 7.1 \\
\hline \multirow[t]{7}{*}{0} & $2001-2015$ & 22-Jun-2006 & 400 & 7.3 \\
\hline & & 20-Aug-2007 & 356 & 6.9 \\
\hline & & 7-Feb-2008 & 328 & 6.7 \\
\hline & & 9-Mar-2009 & 468 & 6.7 \\
\hline & & 28-Feb-2011 & 666 & 7.5 \\
\hline & & 10-Jul-2013 & 490 & 6.9 \\
\hline & & 22-Dec-2013 & 468 & 6.8 \\
\hline
\end{tabular}

Explanation: "Channel-forming hydrologic events" are defined as discharge $>300 \mathrm{~m}^{3} \cdot \mathrm{s}^{-1}$ and/or stage height $>6 \mathrm{~m}$. Data from USGS gage station 04199000 on the Huron River at Milan, Ohio. 


\subsection{Sedimentology of Avulsion Channels}

Trenches and cores were used to assess the conditions of current and abandoned avulsion channels. The avulsion channels all occur in the alluvial reaches. These portions of the Huron River are composed of fine-grained alluvium banks generally $<2-\mathrm{m}$ tall. The primary controls over channel incision and widening are plant roots (Figure 6(a)), standing vegetation and large wood debris (Figure 6(b)), and depth to bedrock (Figure 6(c)).

Infilling of abandoned channels produced a characteristic two-component vertical sequence. Trenches and vibracores reached bedrock at the base of most abandoned channels. Bedrock was overlain by a variety of coarse-grained deposits. These typically consisted of massive gravels (lithofacies $\mathrm{Gm}$ ) and imbricated gravels (lithofacies $\mathrm{Gmi}$ ). Lithofacies $\mathrm{Gm}$ is interpreted as gravel bar platform deposits and lithofacies Gmi is interpreted as bar-head deposits [35]. In some cases the gravel bar deposits are overlain by pebbly coarse-grained sands, interpreted as suprabar platform deposits [35]. In rare instances, trough cross-bedded sand (lithofacies St) and rippled sand (lithofacies Sr) were observed. These are interpreted as chute channel sand dunes and ripples, respectively [31].

The lower coarse-grained sequence is abruptly overlain by significantly finer-grained deposits (Figure 6(d) and Figure 6(e)). These included massive fine-grained sands (lithofacies Smf), planar laminated fine-grained sands (lithofacies $\mathrm{Sl}$ ), laminated and massive silts (lithofacies SSl and SSm) and laminated and massive muds (lithofacies $\mathrm{Fl}$ and $\mathrm{Fm}$ ). Collectively, these are typical proximal overbank deposits, representing infilling of former channels during subsequent flood events.

Although this study examined recent historical changes in the Huron River (constrained by the oldest aerial photograph being from 1950), there was evidence in some trenches and cores of multiple avulsions occurring at the same location. For example, trenches and vibracores from avulsion channels $\mathrm{C} 1$ and C2 both revealed multistory sequences consisting of at least two channel occupation and abandonment successions. This suggests that episodic re-occupation of avulsion channels occurs at specific sites.

\subsection{Sinuosity Changes}

Sinuosity (thalweg path length/direct path length) varied from 1.65 to 1.77 for the study area between 1950-2015. Sinuosity changes for the Huron River are clearly linked to the occurrence of channel avulsions (Table 4). Between 1950-1960, the sinuosity decrease of 1.77 to 1.70 corresponded to avulsions C1, C2, and C3. Between 1960-1969, the sinuosity increase from 1.70 to 1.73 corresponded to no avulsions. From 1969-1977, the sinuosity decrease from 1.73 to 1.71 corresponded to avulsion C4. Between 1977-1979, the sinuosity increase from 1.71 to 1.72 corresponded to no avulsions. From 1979-1988, the sinuosity decrease from 1.72 - 1.66 corresponded to avulsion C5. Between 1988-1995, the sinuosity increase from 1.66 to 1.73 corresponded to no avulsions. From 


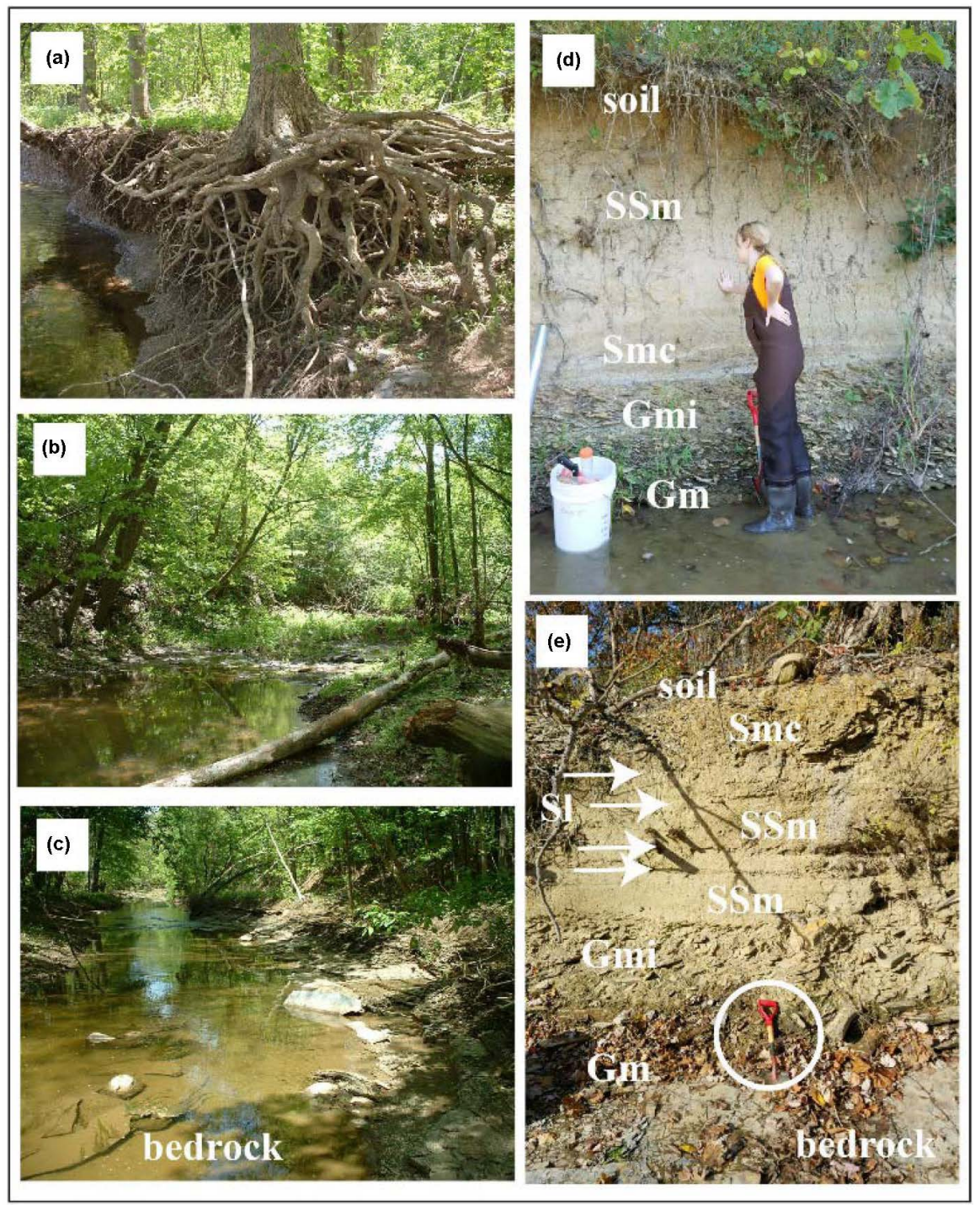

Figure 6. Sedimentology and stratigraphy of avulsion channels. (a) The primary agent for bank stability is vegetation (exposed rootmass of undercut bank); (b) Initial stages of channel abandonment showing influence of vegetation and LWD; (c) Exposed bedrock channel floor in initial stages of channel abandonment; (d) Cutbank and trench exposure of abandoned channel showing gravel bar from active channel phase overlain by massive sand and silt channel-fill sequence; (e) Similar abandoned channel sequence showing gravel bar from active channel phase and massive sand and silt channel-fill sequence with multiple flood layers (arrows).

1995-2001, the sinuosity decrease from 1.73 to 1.67 corresponded to avulsion C6. Finally, between 2001-2015, the sinuosity increase from 1.67 to 1.74 corresponded to no avulsions.

The limits of the dataset are that sinuosity is calculated for the time interval when historical aerial photographs were recorded, but the avulsions occurred in the time interval between one photograph and the next one. Thus the sinuosity values given above (Table 4 ) are not the actual values immediately prior to and following an avulsion event. However, the general trend seen in these data is that 
Table 4. Changes in Huron River sinuosity.

\begin{tabular}{ccccc}
\hline \multicolumn{2}{c}{ Prior to Avulsion(s) } & \multicolumn{2}{c}{ After Avulsion(s) } \\
\hline Date & Sinuosity & Avulsion(s) & Date & Sinuosity \\
\hline 21-Oct-1950 & 1.77 & 3 & 16-May-1960 & 1.70 \\
16-May-1960 & 1.70 & 0 & 22-Mar-1969 & 1.73 \\
22-Mar-1969 & 1.73 & 1 & 29-Apr-1977 & 1.71 \\
29-Apr-1977 & 1.71 & 0 & 20-Sep-1979 & 1.72 \\
20-Sep-1979 & 1.72 & 1 & 9-Apr-1988 & 1.66 \\
9-Apr-1988 & 1.66 & 0 & 15-Mar-1995 & 1.73 \\
15-Mar-1995 & 1.73 & 1 & 1-Apr-2001 & 1.67 \\
1-Apr-2001 & 1.67 & 0 & 3-Jan-2015 & 1.74 \\
\hline
\end{tabular}

Explanation: sinuosity $=$ channel thalweg path length/valley path length.

sinuosity increased between avulsion events to values of $\mathrm{P} \geq 1.72$, and then at some time after this (and possibly at a higher value of $\mathrm{P}$ ), one or more avulsions occurred.

\subsection{Bedrock Fracture Orientations}

Bedrock fractures occurred in sets of parallel orientations (joint sets). Because the fractures were close to vertical, this study focused on the azimuth representing the strike of the individual fracture. In the field, efforts were made to avoid measuring the same fracture repeatedly. The data is summarized as a rose diagram (Figure 7). The azimuth of joint sets falls into two distinct clusters that are approximately $90^{\circ}$ apart. The vector mean of one cluster is 334 and the vector mean of the other cluster is 057 .

The orientation of the channel in bedrock reaches closely corresponds to the orientation of joint sets in the underlying bedrock. In Figure 3, the Huron River makes a series of bends through bedrock reaches that match the orientations of joint sets shown in Figure 7, with a meander wavelength of about $1.2 \mathrm{~km}$. This preferred channel direction is interpreted as the result of enhanced hydraulic quarrying and/or weathering along joint sets resulting in emplacement of the superimposed channel.

\section{Discussion}

\subsection{Influence of Bedrock Reaches on Downstream Avulsions}

Properties of upstream bedrock reaches appear to be transferred to downstream alluvial reaches and control the location and directions of avulsion channels. As shown in Table 5, the directions of upstream bedrock channels matches the orientations of joint sets in the bedrock (Figure 7), clustering at vector means of 057 or 334 . The orientation of the downstream avulsion channels varies only slightly from the directions of the upstream bedrock channels (ranging from $2^{\circ}$ $38^{\circ}$, with a mean and standard deviation of $\left.12.1^{\circ} \pm 13.7^{\circ}\right)$. These data imply that 


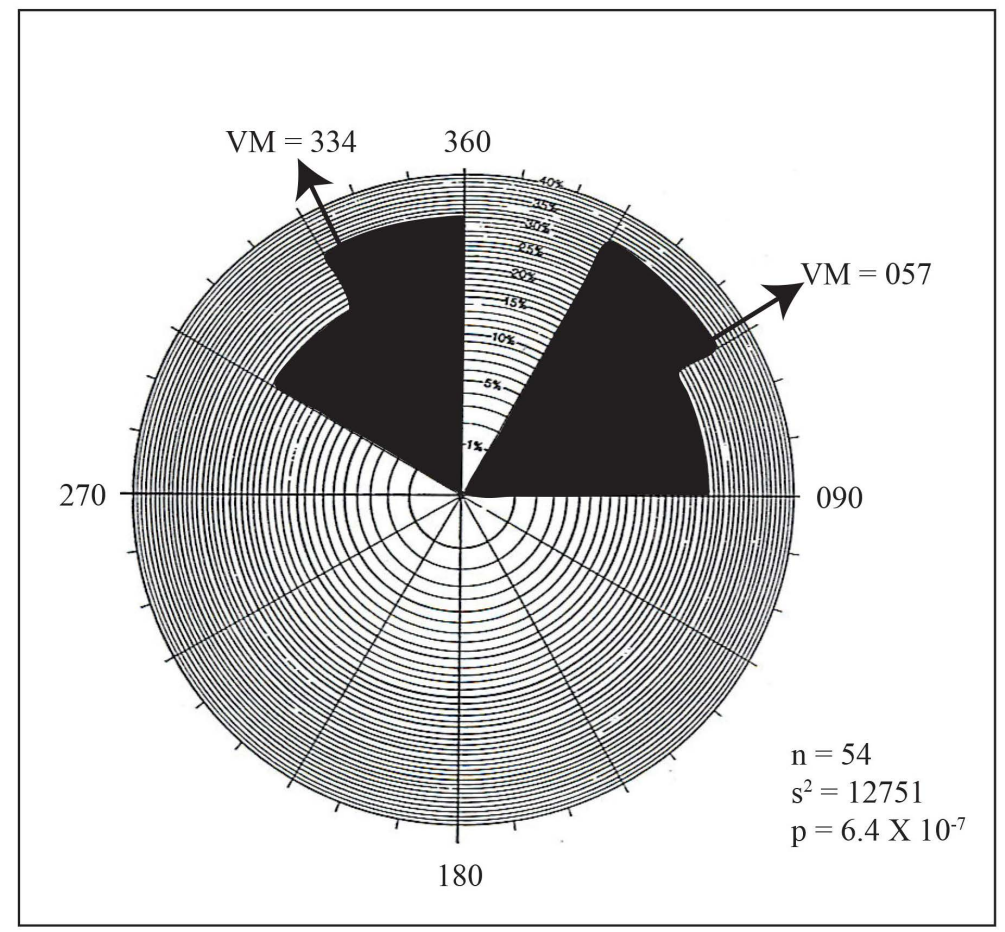

Figure 7. Rose diagram showing the orientation of vertical fractures in the bed of the Huron River, with azimuths clustering in two orthogonal sets. Explanations: $\mathrm{n}=$ number of measurements, $\mathrm{s}^{2}=$ circular variance, $\mathrm{p}=$ Rayleigh test of significance (see text for details).

Table 5. Characteristics of avulsions affected by upstream bedrock reach.

\begin{tabular}{ccccc}
\hline $\begin{array}{c}\text { Avulsion } \\
\text { Channel } \\
\text { Identifier }\end{array}$ & $\begin{array}{c}\text { Azimuth of } \\
\text { Upstream Bedrock } \\
\text { Channel Reach }\end{array}$ & $\begin{array}{c}\text { Azimuth of } \\
\text { Downstream Avulsion } \\
\text { Channel Reach }\end{array}$ & $\begin{array}{c}\text { Exit Angle } \\
\text { (degrees) }\end{array}$ & $\begin{array}{c}\text { Exit Distance } \\
\text { (m) }\end{array}$ \\
\hline C1 & 340 & 342 & 2 & 101 \\
C2 & 080 & 070 & 10 & 116 \\
C3 & 340 & 338 & 2 & 142 \\
C4 & 329 & 344 & 15 & 266 \\
C5 & 340 & 018 & 38 & 175 \\
C6 & 043 & 048 & 5 & 62 \\
& & Mean & $12.1^{\circ}$ & $143.7 \mathrm{~m}$ \\
& & Standard deviation & $13.7^{\circ}$ & $71.0 \mathrm{~m}$ \\
\hline
\end{tabular}

Explanations: Exit angle = deviation between azimuth of upstream bedrock reach and downstream avulsion reach. Exit distance $=$ distance between exit of bedrock reach and upstream end of avulsion channel.

underlying joint sets control the direction of both bedrock and alluvial channels in the Huron River, although bedrock is not exposed in the alluvial channels. Alternatively, the flow exiting the bedrock reaches is directed toward the banks of the alluvial reaches, erodes the bank materials, and influences the sequential development of the avulsion channel. 
The position of the avulsion channel ranges from $62-266 \mathrm{~m}$ downstream of the exit from the upstream bedrock channel, with a mean and standard deviation of $143.7 \pm 71.0 \mathrm{~m}$. This distance does not appear to be controlled by meander dynamics in the alluvial reaches (meander wavelength is about $1.2 \mathrm{~km}$ ). There are no natural or human-constructed obstructions or obstacles that would explain localization of bank erosion and avulsion channel development within such a relatively short distance after the flow "exits" the upstream bedrock channel.

It is suggested that the bedrock channel, strongly aligned by underlying joint set orientations, directs the flow into the downstream alluvial reach, establishing the location and orientation for incipient avulsion channel development, hence these are "inherited" characteristics. Support for this idea is provided by evidence that some of the avulsion channel sites were locations of multiple, episodic avulsion events. Alternatively, it is possible that underlying bedrock fractures are somehow controlling flow directions in the alluvial reaches, even though bedrock is not exposed. It is also possible that avulsion channels develop repeatedly at some sites because the avulsion channel fills are somehow less resistant to subsequent bank erosion than bank materials elsewhere. Avulsion channel-fill sequences have coarse-grained materials at the base, but the upper parts are fine-grained sediment identical to floodplain deposits observed elsewhere in the study area.

\subsection{Avulsions in Rivers with Alternating Bedrock-Alluvial Reaches}

Bedrock channel reaches in the Huron River show active erosion processes, such as mass wasting of the exposed bedrock cliffs where rockfall debris goes directly into the channel, or places with active hydraulic quarrying of bedrock slabs from the channel bottom. There is little alluvial storage in the channel, and where it happens it is typically pool-fills or small pendant bars. Thus the bedrock channel reaches are considered erosional or transport reaches. Alluvial channel reaches in the Huron River show a variety of medial, lateral, point, and confluence gravel bars [26], clearly indicating these are depositional reaches. Overbank processes have produced floodplains, levees, crevasse splays, and avulsion channels [23]. The datasets show progressive changes in sinuosity in the alluvial channel reaches, increasing from $\mathrm{P}=1.65$ to $\mathrm{P}=1.72-1.77$, followed by an avulsion. The avulsion channels typically deviate very little from the direction of the upstream bedrock channel and occur within a short distance (compared to meander wavelength) after flow exits the upstream bedrock channel reach. This suggests that upstream bedrock channel reaches set certain parameters (channel direction, avulsion channel position, and sediment supply) on downstream alluvial reaches, where adjustments in the sediment budget and sinuosity occur.

\section{Summary and Conclusions}

The Huron River demonstrates the complex interactions of rivers with alternat- 
ing bedrock channel reaches and alluvial channel reaches. As expected, the bedrock channels are erosional or transport reaches with little long-term sediment accumulation and the alluvial channels are depositional reaches. Also as expected, the bedrock channels are strongly influenced by characteristics of the underlying bedrock, in this case the orientation of joint sets, and there is little evidence for channel adjustment in these bedrock reaches. What was not expected in this study was evidence for downstream influence of the bedrock channel reaches, such as the location ("exit distance"), orientation of avulsion channels, and repeated occupation of certain avulsion sites-what we term "inherited characteristics". These features may be due to bedrock channels steering the flow toward the banks of the downstream alluvial channels, alternatively bedrock may be exerting control in the alluvial reaches even though it is not exposed in the channel bed materials.

As noted by previous workers, an avulsion is triggered by a hydrologic event, in this case flows greater than the 5-year recurrence interval $(P=0.20)$, which represents channel-forming discharge events. However, because not every such event resulted in an avulsion during this 65-year study interval, such flows are necessary but not sufficient conditions. The more important variable appears to be sinuosity, which increased from $\mathrm{P}=1.65$ to $\mathrm{P}=1.72-1.77$ prior to triggering an avulsion event. This suggests that the "critical sinuosity" [35] for the Huron River is $\mathrm{P} \geq 1.72$, although this might be lower than actual because of the nature of the database (sinuosity is calculated from historical aerial photographs at certain time intervals and avulsions occur between those time intervals). The evidence suggests that upstream bedrock channel reaches impose certain conditions on downstream alluvial channel reaches (sediment supply, channel orientation, exit distance), while the downstream alluvial channel reaches are where adjustments to sediment budgets and sinuosity occur.

\section{Acknowledgements}

We wish to thank Jocelyn Hicks, Lyere Okojie, Allan Adams, and students of the BGSU Surface Water Hydrology class for their assistance in the field. The Ohio Geological Survey provided use of the vibracorer. A portion of this study was a Master's degree thesis project by Potucek. Funding was provided by the BGSU Department of Geology and Mancuso Family Field Scholarship.

\section{Conflicts of Interest}

The authors declare no conflicts of interest regarding the publication of this paper.

\section{References}

[1] Tinker, K. and Wohl, E.E. (1998) A Primer on Bedrock Channels. In: Tinker, K. and Wohl, E.E., Eds., Rivers over Rock: Fluvial Processes in Bedrock Channels, American Geophysical Union, Washington DC, 1-18.

[2] Whipple, K.X. (2004) Bedrock Rivers and the Geomorphology of Active Orogens. 
Annual Reviews of Earth and Planetary Sciences, 32, 151-185. https://doi.org/10.1146/annurev.earth.32.101802.120356

[3] O’Connor, J.E., Mangano, J.F., Anderson, S.W., Wallick, J.R., Jones, K.L. and Keith, M.K. (2014) Geologic and Physiographic Controls on Bed-Material Yield, Transport, and Channel Morphology for Alluvial and Bedrock Rivers, Western Oregon. Geological Society of America Bulletin, 126, 377-397.

https://doi.org/10.1130/B30831.1

[4] Baker, V.R. (1984) Flood Sedimentation in Bedrock Fluvial Systems. In: Koster, E.H. and Steel, R.J., Eds., Sedimentology of Gravels and Conglomerates, Canadian Society of Petroleum Geologists, Memoir 10, 87-98.

[5] Cenderelli, D.A. and Cluer, B.L. (1998) Depositional Processes and Sediment Supply in Resistant-Boundary Channels: Examples from Two Case Studies. In: Tinker, K. and Wohl, E.E., Eds., Rivers over Rock: Fluvial Processes in Bedrock Channels, American Geophysical Union, Washington DC, 105-131. https://doi.org/10.1029/GM107p0105

[6] Tinker, K.J. and Parrish, J. (1998) Recent Adjustments to the Long Profile of Cooksville Creek, an Urbanized Bedrock Channel in Mississauga, Ontario. In: Tinker, K. and Wohl, E.E., Eds., Rivers over Rock: Fluvial Processes in Bedrock Channels, American Geophysical Union, Washington DC, 167-187.

https://doi.org/10.1029/GM107p0167

[7] Whipple, K.X., Hancock, G.S. and Anderson, R.S. (2000) River Incision into Bedrock: Mechanics and Relative Efficiency of Plucking, Abrasion, and Cavitation. Geological Society of America Bulletin, 112, 490-503. https://doi.org/10.1130/0016-7606(2000)112<490:RIIBMA>2.0.CO;2

[8] Jansen, J.D. and Brierley, G.J. (2004) Pool-Fills: A Window to Palaeoflood History and Response in Bedrock-Confined Rivers. Sedimentology, 51, 901-925. https://doi.org/10.1111/j.1365-3091.2004.00643.x

[9] Wohl, E.E. (1992) Bedrock Benches and Boulder Bars: Floods in the Burdekin Gorge of Australia. Geological Society of America Bulletin, 104, 770-778. https://doi.org/10.1130/0016-7606(1992)104<0770:BBABBF>2.3.CO;2

[10] Sklar, L.S. and Dietrich, W.E. (2001) Sediment and Rock Strength Controls on River Incision into Bedrock. Geology, 29, 1087-1090. https://doi.org/10.1130/0091-7613(2001)029<1087:SARSCO >2.0.CO;2

[11] Baker, V.R. and Pickup, G. (1987) Flood Geomorphology of the Katherine Gorge, Northern Territory, Australia. Geological Society of America Bulletin, 98, 635-646. https://doi.org/10.1130/0016-7606(1987)98<635:FGOTKG>2.0.CO;2

[12] Ouimet, W.B., Whipple, K.X., Royden, L.H., Sun, Z. and Chen, Z. (2007) The Influence of Large Landslides on River Incision in a Transient Landscape: Eastern Margin of the Tibetan Plateau (Sichuan, China). Geological Society of America Bulletin, 119, 1462-1476. https://doi.org/10.1130/B26136.1

[13] Montgomery, D.R., Abbe, T.B., Buffington, J.M., Peterson, N.P., Schmidt, K.M. and Stock, J.D. (1996) Distribution of Bedrock Alluvial Channels in Forested Mountain Drainage Basins. Nature, 381, 587-589. https://doi.org/10.1038/381587a0

[14] Collins, B.D., Montgomery, D.R., Schanz, S.A. and Larsen, I.J. (2016) Rates and Mechanisms of Bedrock Incision and Strath Terrace Formation in a Forested Catchment, Cascade Range, Washington. Geological Society of America Bulletin, 128, Article ID: B31340. https://doi.org/10.1130/B31340.1

[15] Schumm, S.A. (1977) The Fluvial System. John Wiley and Sons, New York, 338 p.

[16] Tooth, S., Rodnight, H., Duller, G.A.T., McCarthy, T.S., Marren, P.M. and Brandt, 
D. (2007) Chronology and Controls of Avulsion along a Mixed Bedrock-Alluvial River. Geological Society of America Bulletin, 119, 452-461. https://doi.org/10.1130/B26032.1

[17] Smith, N.D., Cross, T.A., Dufficy, J.P. and Clough, S.R. (1989) Anatomy of an Avulsion. Sedimentology, 36, 1-23. https://doi.org/10.1111/j.1365-3091.1989.tb00817.x

[18] Jones, L.S. and Harper, J.T. (1998) Channel Avulsions and Related Processes, and Large-Scale Sedimentation Patterns Since 1875, Rio Grande, San Luis Valley, Colorado. Geological Society of America Bulletin, 110, 411-421. https://doi.org/10.1130/0016-7606(1998)110<0411:CAARPA>2.3.CO;2

[19] Jones, L.S. and Schumm, S.A. (1999) Causes of Avulsion: An Overview. In: Smith, N.D. and Rogers, J., Eds., Fluvial Sedimentology VI, International Association of Sedimentologists, Special Publication 28, 179-278. https://doi.org/10.1002/9781444304213.ch13

[20] Slingerland, R. and Smith, N.D. (2004) River Avulsions and Their Deposits. Annual Review of Earth and Planetary Sciences, 32, 257-285. https://doi.org/10.1146/annurev.earth.32.101802.120201

[21] Ohio Environmental Protection Agency (2005) Total Maximum Daily Loads for the Huron River Watershed. Ohio Environmental Protection Agency, Huron River TMDL Program, Columbus, 97 p.

[22] U.S. Geological Survey-National Water Information System (2016) Data for Gage 04199000. https://waterdata.usgs.gov/nwis/uv?site_no=04199000

[23] Potucek, M.J. (2017) Channel Change Processes and Rates in a Mixed Alluvial-Bedrock River, Huron River, North-Central Ohio (U.S.A.). M.S. Thesis, Bowling Green State University, Bowling Green, 190 p.

[24] Schwietering, F. (1979) Devonian Shales of Ohio and Their Eastern and Southern Equivalents. U.S. Department of Energy, Report METC/CR-79/2, Washington DC, $73 \mathrm{p}$.

[25] Coogan, A.H. (1996) Ohio's Surface Rocks and Fossils. In: Feldman, R.M. and Hackathon, M., Eds., Fossils of Ohio, Ohio Department of Natural Resources, Division of Geological Survey, Bulletin 70, Columbus, 31-50.

[26] Evans, J.E., Huxley, J.M. and Vincent, R.K. (2007) Upstream Channel Changes Following Dam Construction and Removal Using a GIS/Remote Sensing Approach. Journal of the American Water Resources Association, 43, 1-15. https://doi.org/10.1111/j.1752-1688.2007.00055.x

[27] Neill, C.R. (1973) Hydraulic and Morphologic Characteristics of the Athabasca River near Fort Assiniboine. Alberta Research Council, Edmonton, Highway and River Engineering Division Report REH/73/3, 23.

[28] Church, M. (1983) Pattern Instability in a Wandering Gravel Bed Channel. In: Collinson, J.D. and Lewin, J., Eds., Modern and Ancient Fluvial Systems, International Association of Sedimentologists, Special Publication 6, Oxford, 169-180. https://doi.org/10.1002/9781444303773.ch13

[29] ASTM (2017) E11-17 Standard Specification for Woven Wire Test Sieve Cloth and Test Sieves. ASTM International, West Conshohocken. http://www.astm.org

[30] Folk, R.L. (1968) Petrology of Sedimentary Rocks. Hemphill's, Austin Texas, 194 p.

[31] Miall, A.D. (1977) A Review of the Braided River Environment. Earth Science Reviews, 13, 1-62. https://doi.org/10.1016/0012-8252(77)90055-1

[32] Nemec, W. (1988) The Shape of the Rose. Sedimentary Geology, 59, 149-152. https://doi.org/10.1016/0037-0738(88)90105-4 
[33] Krause, R.G.F. and Geijer, T.A.M. (1987) An Improved Method for Calculating the Standard Deviation and Variance of Paleocurrent Data. Journal of Sedimentary Petrology, 57, 779-780. https://doi.org/10.1306/212F8C3D-2B24-11D7-8648000102C1865D

[34] Curray, J.R. (1956) The Analysis of Two-Dimensional Orientation Data. Journal of Geology, 64, 117-131. https://doi.org/10.1086/626329

[35] Hooke, J.M. (2004) Cut-Offs Galore! Occurrence and Causes of Multiple Cutoffs on a Meandering River. Geomorphology, 61, 225-238.

https://doi.org/10.1016/j.geomorph.2003.12.006 